\title{
Working time accounts and firm performance in Germany
}

\author{
Lutz Bellmann ${ }^{1}$ and Olaf Hübler ${ }^{2^{*}}$
}

\author{
* Correspondence: \\ huebler@ewifo.uni-hannover.de \\ ${ }^{2}$ Institut für Empirische \\ Wirtschaftsforschung, Leibniz \\ Universität Hannover, \\ Königsworther Platz 1, D-30167 \\ Hannover, Germany \\ Full list of author information is \\ available at the end of the article
}

\begin{abstract}
This study investigates whether working time accounts affect the performance of German establishments based on the Establishment Panel from the Institute for Employment Research. The major results are: productivity and investments are positively correlated with working time accounts. No significant effects of working time accounts can be detected on wages and on operating surplus. On average, we find a tendency towards negative effects on profits. This result is less likely in phases of low product demand and for export-oriented, large establishments with a high share of skilled workers. Under strong sales fluctuations, we find positively significant effects on the operating surplus.
\end{abstract}

JEL: C22, D21, J21, J22, J24

Keywords: Working time accounts, Establishments, Productivity, Wages, Investments, Operating surplus, Profits, Qualified workers, Sales fluctuations

\section{Introduction}

The discussion of flexible working time has a long tradition in the economic, psychological and sociological literature (Berg et al. 2004; Crompton 2002; Dex and Scheibl 2001; Houseman 2001; Kelliher and Anderson 2010; Orpen 1981; Schein et al. 1977). Working time accounts (WTA) are a specific instrument to allow some working time flexibility around a planned working time framework and have existed in German plants since the 1960s. The flexible working hours (Gleitzeit) discussion combined with the decoupling of working hours and company operating hours has promoted the breakthrough of WTA (Groß et al. 2000). In recent years, an increasing number of establishments have implemented WTA. Over the course of the flexibility debate, labor market reforms and the Great Recession, this instrument has become more popular.

Both employers and employees can benefit from WTA (Seifert 2004): employers are interested in the ability to adjust employees' daily or weekly working time if the demand for and availability of personnel vary over time. They are able to adapt the working volume without layoff and (re-)hiring personnel. Thus, employers can avoid layoff and recruitment costs. Employees, and especially women, can better combine paid work with care of children and elderly persons because care cannot be fully pre-planned. Employees are able to reconcile their work-life balance. The positive and negative effects of flexible working time on employees also affect firm's profits. If employers are able to improve the working conditions of their employees, they can fill vacant positions more quickly and at

(c) 2015 Bellmann and Hübler. Open Access This article is distributed under the terms of the Creative Commons Attribution 4.0 International License (http://creativecommons.org/licenses/by/4.0/), which permits unrestricted use, distribution, and reproduction in any medium, provided you give appropriate credit to the original author(s) and the source, provide a link to the Creative Commons license, and indicate if changes were made. 
a lower cost. Establishments have possibilities to weaken negative and strengthen positive effects. Better capacity utilization can be achieved by WTA insofar as capital costs can be saved and storage costs can be reduced. A more efficient utilization of labor is a central objective of WTA (Zapf 2012). Employers are better able to meet demand fluctuations and can better avoid the wage costs associated with workforce under-utilization.

Negative effects of WTA are to be expected if employees use this flexible working time instrument at different times than the employer desires. Firms would like for working time hours to be reduced during a recession. If demand for products increases, they want to expand the scope of work. Overtime hours and therefore positive working time credits are desired. However, workers want to adjust their working hours to their preferred timing, namely, according to their preferred leisure and work trade-off. This means, one perspective might be that the flexible use of WTA by employees in times of high demand may affect profits negatively. And an alternative view states that the flexible use of WTA by employers in times of low demand may save costs and affect output positively.

As it is noted that WTA can be in the interest of both employees and employers, the best way to analyze the effects of WTA would be to use integrated establishment and individual data. This type of data is available by LIAB - Linked Employer-Employee Data from the Institute for Employment Research (IAB) of the German Federal Employment Agency (BA). However, information on employees' behavior with respect to WTA is missing in this data set. Currently, a separate analysis based on establishment and individual data is only possible. Most existing studies concentrate on the latter issue. Therefore, our contribution is focused on the establishments' perspective.

We contribute to the WTA literature by providing a more detailed analysis of working time accounts with respect to firm effects. First, we discuss the impact of WTA on productivity not only during the Great Recession but also over a period of six years, including the recession period. This enables permanent effects to be detected. Second, we supplement the investigation of WTA effects on further important business indicators, especially with respect to the wages per employee, investments and profits. This provides us with insights about the question of whether WTA have positive effects on firm performance. Third, we investigate whether interaction effects of WTA with other influencing factors can be uncovered. Among others, we can indirectly show whether our results are in accordance with the two mentioned hypotheses. Fourth, a subgroup analysis is carried out. We show that the effects differ between establishments with a high share and a low share of skilled workers, between companies with strong and only weak sales fluctuations. Moreover, we present the effects of WTA under different agreements on the compensation period of time credits and debits within WTA regimes. This reveals whether the WTA effects are heterogeneous with respect to specific WTA contracts.

Besides graphs and t-tests that reveal the development of the share of WTA and demonstrate in which characteristics WTA and non-WTA firms differ, we apply econometric methods. The least angle regression approach serves as the basis of variable selection. OLS estimates as benchmarks are supplemented by two-stage least squares for panel data. Our major results are as follows: productivity and investments are enhanced by WTA. No influence can be discovered on wages per employee and operating surplus. The latter result is not maintained in establishments under strong sales variation. 
In this case, significantly positive effects on operating surplus are observed. In general, profits are negatively influenced by WTA. This outcome is less likely for firms with a high share of qualified workers. In times of low demand during the Great Recession, WTA help to reduce profit losses.

The rest of the paper is organized as follows: In section 2, the major empirical results in the related literature are presented in a brief overview. Section 3 is focused on the data set and descriptive statistics. In section 4, the applied methods and the econometric results are discussed. Section 5 concludes the paper.

\section{Related empirical literature}

Various studies exist on flexible working hours in Europe (Chung and Tijdens 2009; European Foundation for the Improvement of Living and Working Conditions 2012a, 2012b; Platenga and Remery 2010). Chung and Tijdens (2009) present the working time arrangements in $21 \mathrm{EU}$ member states based on the Establishment Survey on Working Time 2004/2005.

More detailed information on the use of WTA and their determinants is available from Germany (Bellmann and Gewiese 2004; Herzog-Stein and Zapf 2014; Lott 2013; Ludewig 2001; Wotschack and Hildebrandt 2007; Zapf 2012; Zickert 2007). Based on the IAB Establishment Panel, Bellmann et al. (2012) show that the proportion of WTA establishments increased slightly between 2002 and 2008. The IAB Working Time Calculation shows strongly varying WTA balances within the period 1991-2010, with a dramatic slump in 2008/2009 and complete recovery in the following year (Zapf 2012, p.48). During the crisis, employees' working time credits were eliminated. However, no significantly different use of WTA is reported during the crisis compared with other years. Herzog-Stein and Zapf (2014) stress that WTA played an important role in overcoming the negative effects of the Great Recession in Germany. Zapf and Brehmer (2010) argue that the WTA were successful. Their major argument is that companies with WTA have more quickly matched their working time with product demand during and after the Great Recession through the reduction of time credits within WTA arrangements than other firms.

The use of long-term WTA depends on firm size, the share of female employees and the existence of works councils (Wotschack and Hildebrandt 2007). Large firms perceive advantages in support of early retirement options. Small firms with a high share of female employees emphasize that the use of long-term WTA helps by providing options for family leaves or temporary part-time schedules.

No detailed information exists on the specific WTA arrangement except in case studies, e.g., in Lindecke (2008). However, in the latter case, no generalized statements on the effects of WTA are possible. Empirical investigations on WTA with large individual datasets solve this problem. This does not meet our main research interest because we want to analyze the effects on establishments. Nevertheless, the results can demonstrate in which way individuals are affected by WTA. This can reveal, in comparison with establishment analyses, whether firms and employees want to build time credits at the same time and to remove them during the same period. If not, conflicts are possible.

Further insights into effects of flexible working hours on employees are provided by Possenriede (2014) using Dutch household panel data from 2002 to 2010. He finds that 
the moderate use of flexi-time does not affect employer-paid training and promotions, except for female workers. Their chances of a promotion decrease if they make use of flexi-time. Frequent use of flexible arrangements by employees is sanctioned by the employer. In that regard, we do not know so much about the objectives of establishments in relation to flexi-time and WTA. Of more interest for the employer is the result that flexi-time is negatively associated with sickness absenteeism, especially with the duration of absence. The effects on the number of working hours are only moderate and, in many cases, ambiguous. Observed increases are driven by more unpaid overtime hours.

A specific kind of flexible working time is analyzed by Beckmann et al. (2015). Based on the German Socio-Economic Panel from 2003 to 2011, they investigate the impact of self-managed working time on employee effort: 13.9 to 15.0 percent of the employees could determine their working time in this period at their own discretion. The study finds higher effort of workers with self-managed working time in comparison to workers with fixed working hours. This means employers can benefit. However, when the investigation controls for observed and unobserved characteristics and endogeneity, this positive effect is only moderate, mainly driven by strong work ethic and intrinsic motivation but not by extrinsic motivators. Increased effort cannot be explained by the theory of reciprocity. Employees' shirking as a reaction to self-managed working time is ruled out by this investigation.

Empirical investigations on WTA effects based on IAB Establishment Panel data are carried out by Bellmann and Gerner (2011); Gerner (2012) and Balleer et al. (2014). These studies are focused on the influence of WTA on economic establishment indicators during the Great Recession. WTA play only a moderate role in employment (Bellmann and Gerner 2011). Using descriptive statistics and multivariate estimates, Gerner (2012) finds that during the crisis, establishments were strongly hit by reduced employment, but this decline was smaller than their decrease in sales. The bivariate analysis supports the hypothesis that WTA contribute to a weaker reduction of employment. Firms hoarded employees, resulting in lower productivity. A multivariate investigation cannot detect significant differences in the change in labor productivity between WTA and non-WTA firms. This could mean that WTA do not achieve the major objective, namely, the stabilization of employment.

Balleer et al. (2014) confirm these doubts. WTA were not the major driver of the stable employment level in Germany during the Great Recession. They find that the separation and hiring reactions to profit changes are similar in firms with and without WTA. The only significant effect of WTA is revealed by their effect on short-time work. If revenue expectations increase, the reduction in the number of short-time workers is larger in firms with WTA.

In sum, the empirical results produced to date cannot ultimately make clear whether WTA are generally beneficial for establishments. On the one hand, the adoption and use of WTA have intensified in Europe, especially in Germany. This speaks in favor of a successful instrument. On the other hand, during the Great Recession, WTA were less successful in employment stabilization than expected. Based on theoretical considerations, Launov and Wälde (2014) are skeptical because the effect on unemployment depends on the dynamics of the goods market and the particular productivity type of a firm. 


\section{Data and descriptive statistics}

The data used in this study come from the German IAB Establishment Panel (Fischer et al. 2009). The panel began in 1993 with an annual survey of West German establishments and was extended to East Germany in 1996. The sample selection is representative of German states (Bundesländer), industries, and establishment size; 16,000 firms are questioned annually about a wide range of labor market topics. The interviews are conducted face-to-face by professional interviewers. This ensures a high data quality and a response rate of 83 percent on average.

The establishments surveyed employ one or more employees covered by social insurance. We use the surveys from 2008 to 2014. In practice, only variables from 2008 until 2013 are considered because some key information collected in year t pertains to the past year. In this period, information on working time accounts is available for every year. Positive time credits of WTA are interpreted as overtime work. We know whether an establishment has WTA, measured as a dummy variable (WTA $=1$ if working time accounts exist; WTA $=0$ otherwise). A data problem arises related to WTA in the IAB Establishment Panel. The filtering procedure in the questionnaire differs in even and odd years. In even years, firms without overtime work are excluded when asked whether WTA exist. In odd years, they are included. This means the number of firms with WTA is lower in even years. Artificial cycles are induced. In order to clear up this incompatibility, we changed the WTA status in any year $(t)$ if in the year before $(t-1)$ and after $(t+1)$ the statements differ, e.g., if we have observed WTA $=0$ in 2012 but $\mathrm{WTA}=1$ in 2011 and 2013. Then, we assume that WTA = 1 in 2012 would be answered if the filter in 2012 would be the same as in 2011 and 2013. This adjustment is based on the guess that the abolishment of WTA does not follow in the next year, directly after the introduction of WTA. Costs of the introduction usually hinder such a mechanism. The development of WTA is presented in Fig. 1.

Table 1 displays the statistically significant differences in firm characteristics between WTA and non-WTA firms based on pooled data from the period 2008-2013. We find that productivity is higher in firms with WTA. Relatively speaking, WTA help firms to produce more efficiently. Furthermore, we find that WTA in Germany are more likely to occur in larger firms than in smaller ones. This finding can also explain that, on

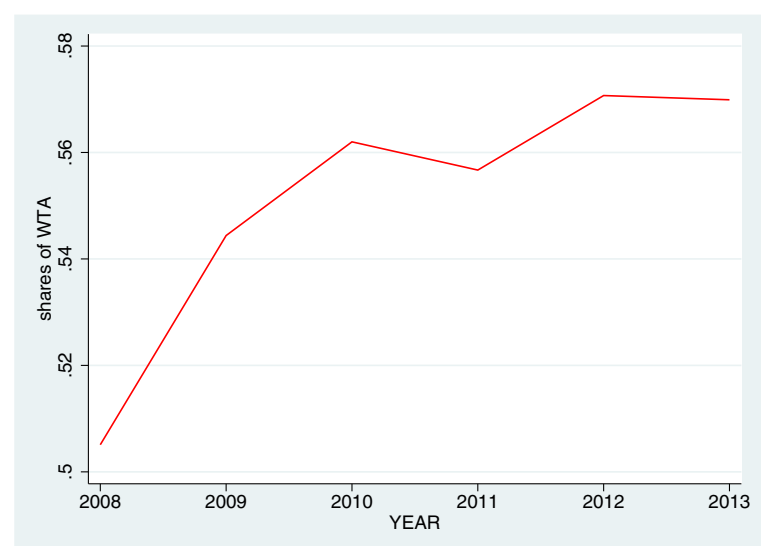

Fig. 1 Working time accounts in Germany. Shares based on average values per year. Source: IAB Establishment Panel 2008-2013 
Table 1 Descriptive statistics of establishment characteristics, split by WTA and non-WTA firms and pooled over 2008-2013, $t$ tests of the difference between means of the two types of firms

\begin{tabular}{|c|c|c|c|c|c|}
\hline & WTA = & & WTA $=($ & & $t$-test \\
\hline & mean & sd & mean & sd & t value \\
\hline $\log ($ PRODUCTIVITY) & 11.600 & (0.93) & 11.215 & (0.96) & $76.42^{* * *}$ \\
\hline log(WAGES per EMPLOYEE) & 7.599 & $(0.50)$ & 7.189 & $(0.66)$ & $150.54^{* * *}$ \\
\hline $\log (F \mid R M ~ S I Z E)$ & 3.908 & (1.66) & 2.500 & $(1.40)$ & $183.04^{* * *}$ \\
\hline log(INVESTMENTS) & 12.181 & (2.39) & 10.645 & (2.05) & $148.10^{* * *}$ \\
\hline $\log (G R A D U A T E S)$ & 1.534 & (1.83) & 0.520 & (1.13) & $159.35^{* * *}$ \\
\hline log(SKILLED WORKERS) & 3.333 & $(1.75)$ & 1.823 & (1.47) & $184.34^{* * *}$ \\
\hline log(OPERATING SURPLUS) & 14.477 & (1.99) & 12.856 & $(1.71)$ & $160.05^{* * *}$ \\
\hline PROFITS & 3.302 & $(1.02)$ & 3.183 & $(1.00)$ & $23.72^{* * *}$ \\
\hline LABOR HOARDING & 0.454 & $(0.50)$ & 0.530 & $(0.50)$ & $-34.04^{* * *}$ \\
\hline PART-TIME WORK & 0.851 & $(0.36)$ & 0.769 & $(0.42)$ & $46.83^{* * *}$ \\
\hline TEMPORARY WORK & 0.207 & $(0.41)$ & 0.055 & $(0.23)$ & $99.61^{* * *}$ \\
\hline EXTRA PAYMENTS & 0.206 & $(0.40)$ & 0.108 & $(0.31)$ & $59.24^{* * *}$ \\
\hline REORGANIZATION & 0.026 & $(0.16)$ & 0.008 & $(0.09)$ & $29.87^{* * *}$ \\
\hline COMPETITIVE PRESSURE & 2.996 & (1.04) & 2.910 & $(1.01)$ & $18.56^{* * *}$ \\
\hline NEW PRODUCTS & 0.511 & $(0.50)$ & 0.351 & $(0.48)$ & $72.18^{* * *}$ \\
\hline NEW PROCEDURES & 0.225 & $(0.42)$ & 0.105 & $(0.31)$ & $72.07^{* * *}$ \\
\hline TECHNICAL STATE & 2.172 & $(0.72)$ & 2.257 & $(0.77)$ & $-25.30^{* * *}$ \\
\hline
\end{tabular}

Note: ${ }^{* * *} p<0.01$

average, WTA firms have greater total sales and investments than other establishments. Finally, it should be mentioned that WTA firms have more graduates and skilled workers. This table reveals that poor profits are less widespread in WTA firms than in non-WTA firms.

Figure 2 displays the development of labor productivity (sales per employee) in WTA and non-WTA firms. Over the complete period, the productivity of WTA firms is significantly higher than in other firms. The figure reveals stronger productivity fluctuations for non-WTA firms. This supports the notion that WTA contribute to stabilization.

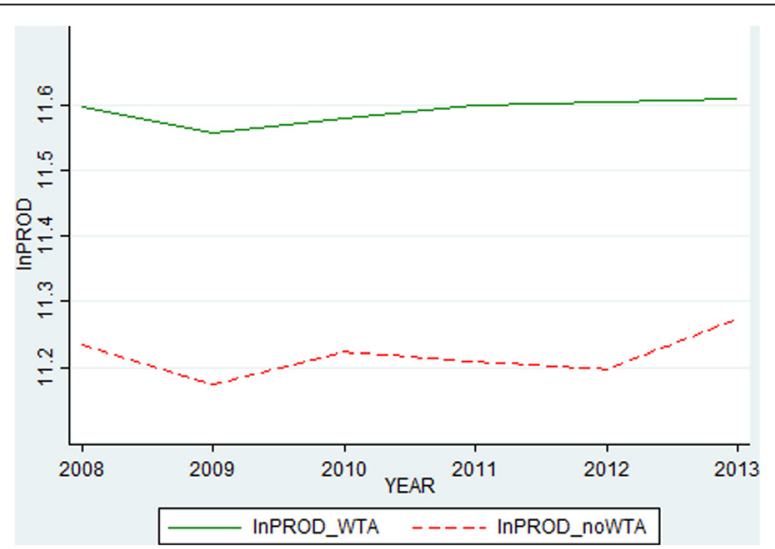

Fig. 2 Firm productivity split by WTA and non-WTA firms. Germany 2008-2013. Source: IAB Establishment Panel 
However, during the Great Recession, WTA could not prevent a more pronounced contraction of productivity. An obvious decline is observed in 2009.

\section{Methods and econometric results}

\subsection{Empirical approach}

The starting point of multivariate estimates is the determination of the influence of WTA on labor productivity in order to compare them with existing investigations. A first problem is the selection of control variables. For the labor productivity estimation, the specification can be based on the production theory and a wide range of welldeveloped production functions. Nevertheless, the decision is unclear, and we want to analyze further performance functions for which no clear theory exists. Therefore, we use the least angle regression selection approach (LARS - Efron et al. 2004) to choose variables from among available firm characteristics. Assume the productivity function (main equation) is:

$$
\log \left(P R O D_{i t}\right)=\beta_{0}+\beta_{1} W T A_{i t}+x_{i t}^{\prime} \beta_{2}+u_{i t}=: \beta_{0}+\dot{x}_{i t}^{\prime} \beta+u_{i t},
$$

where $\mathrm{i}=1, \ldots, \mathrm{N}$ is the index of firms, $\mathrm{t}=1, \ldots, \mathrm{T}$ is the index of time periods, $\beta^{\prime}=$ $\left(\beta_{0}, \beta^{\prime}\right)=\left(\beta_{0}, \beta_{1}, \ldots, \beta_{K}\right)$ is the coefficient vector, and $u_{i t}$ is the error term.

For the $\log$ productivity function $(\log (\mathrm{PROD}))$, the following determinants are selected:

$$
\begin{aligned}
& \mathrm{X}=\text { (LABOR HOARDING, FIXED-TERM EMPLOYMENT, PART-TIME WORK, } \\
& \text { TEMPORARY WORK, OVERTIME WORK, log(GRADUATES), } \\
& \text { log(SKILLED WORKERS), EXTRA PAYMENTS, DEPARTED EMPLOYEES, } \\
& \text { LAY-OFFS, QUITS, MUTUAL DISMISSALS, RELOCATIONS, } \\
& \text { RETIREMENTS, EARLY RETIREMENTS, log(FIRM SIZE), } \\
& \text { PLANT CLOSURE, OUTSOURCING, STARBUST, REORGANIZATION, } \\
& \text { COMPETITIVE PRESSURE, NEW PRODUCTS, NEW PROCEDURES, } \\
& \text { TECHNICAL STATE, log(INVESTMENTS })
\end{aligned}
$$

The order of the variables indicates their statistical importance. This means that the variable LABOR HOARDING is first selected by the least angle regression as the most important influence among the given set of establishment characteristics.

Pooled OLS estimates neglect possible unobserved establishment effects $\left(u_{\mathrm{i}}\right)$. In this case, we have $u_{i t}=u_{i}+\varepsilon_{i t}$, where the latter term is the classical error term. Based on the Breusch-Pagan Lagrange multiplier approach, we can test whether the null hypothesis that no such effects exist has to be rejected. Hausman tests allow us to ascertain whether random or fixed effects estimates are superior. A further problem is the interdependency between productivity and WTA. On the one hand, WTA may decrease or increase the productivity, as described in Section 1. On the other hand, low productivity may induce the adoption of working time accounts in order to improve competitiveness. In this case, a WTA function is formulated (first-stage equation)

$$
W T A_{i t}=\gamma_{0}+\gamma_{1} \log \left(P R O D_{i t}\right)+z_{i t}^{\prime} \gamma_{2}+v_{i t}=: \gamma_{0}+\widetilde{z}_{i t}^{\prime} \gamma+v_{i t}
$$

We estimate within two-stage least squares for panel data models (W2SLS; Baltagi 2005, p.114) 


$$
\beta_{W 2 S L S}=\left(\dot{X}_{1}^{\prime} P_{\ddot{X} 1} \dot{X}_{1}\right)^{-1} \dot{X}_{1}^{\prime} P_{\ddot{X} 1} \dot{Y}_{1} ; V\left(\beta_{W 2 S L S}\right)=\sigma_{\varepsilon 11}^{2}\left(\dot{X}_{1}^{\prime} P_{\ddot{X} 1} \dot{X}_{1}\right)^{-1}
$$

where $\dot{X}=($ WTA,X) are the determinants of the main structural equation (1) of our simultaneous two equation model. $\ddot{\mathrm{X}}=(\mathrm{X}, \mathrm{Z})$ include all exogenous variables of the complete model; $\sigma_{\varepsilon 11}^{2}$ is the variance of the classical part of the error term in the main equation (1). Multiplied with the weight matrix $\mathrm{Q}$, the following expressions are defined: $\dot{\mathrm{X}}_{1}=\mathrm{Q} \dot{\mathrm{X}}, \ddot{\mathrm{X}}_{1}=\mathrm{Q} \ddot{\mathrm{X}}$ and $\dot{\mathrm{y}}_{1}=\mathrm{Q} \log (\mathrm{PROD})$, where $\mathrm{Q}=\mathrm{I}_{\mathrm{NT}}-\mathrm{P}$. The scalar $\mathrm{N}$ is the number of firms, and $\mathrm{T}$ the number of time periods. The matrix $\mathrm{P}$ is the Kronecker product between the identity matrix $\mathrm{I}_{\mathrm{N}}$ and the matrix of ones of dimension $\mathrm{T}$.

Well-founded instruments based on policy measures or institutional rules that are not correlated with the error term are not available. Therefore, identifying variables have to be constructed by observational information from the dataset. The average industry WTA (a_indusWTA) or the average regional (a_regWTA) variable is a possibility. The disadvantage of these indicators is that if firms never switched region or industry, then these variables are time-invariant and would drop out of the model after applying a within- or a first-differences estimator.

We use the classified predicted probability of WTA (prWTA_c) as an instrument. The prWTA_c variable is determined in two steps. In the first step, probit estimates of WTA are executed. Based on these estimates, the probability that a firm has WTA is calculated (prWTA). In the second step, this variable is classified into 10 intervals (prWTA_c $=1$ if $0<$ prWTA $<=0.1$, prWTA_c $=2$ if $0.1<$ prWTA $<=0.2, \ldots$, prWTA_c $=10$ if $0.9<$ prWTA $<=1$ ). The intention of these constructions is to obtain a variable that is strongly correlated with WTA but uncorrelated with the error term of the main equation. Tests for endogeneity, over-identifying restrictions and weak instruments see Appendix (Table 8), columns EXO, OIR and WI - are used to check whether the applied identifying variables fulfill the necessary conditions. Also this instrument can be criticized because identification comes only from the different functional form of prWTA_c compared with WTA. Because we do not focus on causal effects, but from a statistical view, endogeneity problems shall be solved, the argument is not so relevant.

Productivity is not the only indicator to evaluate whether WTA are beneficial for establishments. Following Addison et al. (2001), typical further performance indicators are labor fluctuations, departures, hires, wages, innovation and profitability. We focus on wages per employee, investments and profitability. We test whether WTA also influence investments because innovations are expressed by investments and the latter affect productivity. Influence on firms' costs is also relevant, especially for employee wages. Our last step is to test a relationship between profits and WTA. If there is a significantly positive correlation between these two indicators, we have strong evidence that WTA are beneficial for firms. As a supplement, interaction models are estimated. This means the WTA dummy is multiplied by specific firm's characteristics and incorporated in the profit function. So we can prove whether WTA effects differ in establishments with typical characteristics from others.

Finally, we investigate whether WTA effects differ between subgroups. On the one hand, we split firms into groups with high and low sales variability, as well as firms with a high share and a low share of skilled workers. On the other hand, based on the maximal agreed compensation duration of time credits and time debits, the effects are 
compared. We distinguish between the following compensation periods: compensation period up to one year, longer than one year, no fixed compensation period. The hypotheses are the following: (i) the stronger the fluctuations of the product demand, the more a firm benefits from WTA; (ii) the lower the share of skilled workers, the more negative profit effects can be expected; and (iii) the longer the compensation period, the more likely is it that actual working time matches the actual demand for labor.

\subsection{Econometric results for the entire sample}

As establishment characteristics, we analyze the following performance variables, most of which are measured in logarithms $(\log ()$.$) : productivity, wages per employee, and in-$ vestments. Finally, we are interested in the establishment's profits measured by a categorical variable. The IAB Establishment Panel reports whether the profit situation is very good, good, satisfactory, sufficient or poor. As an alternative, we use the operating surplus (=sales-preliminary work-wages) as a proxy for profits.

OLS estimates-see Table 2-provide no significantly positive WTA effects on productivity and weakly negative effects on profits. Wages per employee and investments increase by WTA. Firms with WTA have a higher propensity than other firms to adopt overtime work (Bellmann and Hübler 2015). An extension of overtime work is plausible when no overtime premiums have to be paid within the WTA bounds. Then, there are firm advantages. However, there are resulting higher costs. WTA in the $\log$ (PRODUCTIVITY) estimation do not display the expected significant impact. A reason for this unexpected result might be the neglect of the interdependency between productivity and WTA - see Section 4.1 and the outcome of Appendix (Table 8), column EXO. The difference between columns (1) and (2) in Table 2 is that in the latter the export share (EXPORT) is incorporated as an additional regressor. The influence of EXPORT is significant in all five estimates-not reported in Table 2-but the variation of WTA compared with column (1) is negligible except in the investment function.

Table 2 Ordinary least squares (OLS) estimates for different establishment performance functions with a working time accounts (WTA) dummy as a regressor

\begin{tabular}{llllll}
\hline & \multicolumn{1}{l}{$(1)$} & & $(2)$ & \\
\cline { 2 - 3 } & $\beta($ WTA $)$ & std.err & & $\beta($ WTA $)$ & std.err \\
\hline $\log ($ PRODUCTIVITY) & 0.004 & 0.010 & & 0.005 & 0.010 \\
$\log$ (WAGES per EMPLOYEE) & $0.073^{* * *}$ & 0.004 & & $0.064^{* * *}$ & 0.005 \\
$\log ($ INVESTMENTS) & $0.171^{* * *}$ & 0.015 & & $0.112^{* * *}$ & 0.016 \\
$\log$ (OPERATING SURPLUS) & 0.012 & 0.009 & & $0.015^{* * *}$ & 0.009 \\
PROFITS & $-0.019^{*}$ & 0.010 & & $-0.023^{* * *}$ & 0.010 \\
\hline
\end{tabular}

Notes: PRODUCTIVITY is measured by the ratio of total business volume and total number of employees. The control variables are LABOR HOARDING, FIXED-TERM EMPLOYMENT(D), PART-TIME WORK(D), TEMPORARY WORK(D), log(GRADUATES), log(SKILLED WORKERS), log(FIRM SIZE), EXTRA PAYMENTS(D), QUITS, MUTUAL DISMISSALS, RELOCATION, RETIREMENTS, EARLY RETIREMENTS, PLANT CLOSURE(D), OUTSOURCING(D), STARBUST(D), REORGANIZATION(D), COMPETITIVE PRESSURE, NEW PRODUCTS(D), NEW PROCEDURES(D), TECHNICAL STATE, Y2008(D), Y2009(D), Y2010(D), Y2011(D), and Y2012(D). Variables with $D$ in parentheses indicate that these are dummies. PROFITS are measured by an ordinal scale: 1 - poor, 2 - sufficient, 3 - satisfactory, 4 - good, 5 - very good. Further ordinal scaled variables are COMPETITIVE PRESSURE ( 1 - no pressure, 2 - minor pressure, 3 - medium pressure, 4 - substantial pressure) and TECHNICAL STATE ( 1 - state of the art, ..., 5 - obsolete). LABOR HOARDING is assumed if the firm has answered that under the assumption of extensive demand a higher business volume could be managed with the available personnel and plant equipment. REORGANIZATION is defined as organizational developments that resulted from the integration of other establishments or establishment units into the company; robust standard errors. In column (2) the specification is supplemented by EXPORT, the export share; ${ }^{*} p<0.1,{ }^{* * *} p<0.01$ 
As an extension of the analysis, we undertake instrumental variables panel estimates. The hypothesis of no time-invariant establishment effects is rejected-see Appendix (Table 8), column BP-and the fixed effects estimator is preferred-see Appendix (Table $8)$, column HAUS. The productivity and investment effects of WTA are significantly positive. For the productivity function, the complete estimates with and without industry and region dummies are shown in Appendix (Table 9). In addition to the positive WTA effect, we find that labor hoarding significantly reduces productivity, while relocations and reorganizations enhance productivity. We do not find significant wage effects of WTA. Separate estimates for the output and the number of employees as a supplement to the productivity estimation show that the positive WTA effect on productivity is driven by the output and not by the number of employees (Bellmann and Hübler 2015).

The interpretation of the profit effect in Table 3 is not so obvious. As in the OLS estimates, no positive profit effects of WTA are revealed. The negative sign of the coefficient means that profits are lower in WTA companies than in other firms. Increasing wages per employee do not seem to be a decisive factor. The WTA effect is insignificant. However, a rise of absolute wage costs can be responsible. E. g., in Bellmann and Hübler (2015) we find that the number of departed workers declines when a WTA system is introduced. Insofar, wage costs may rise. Under-investment might be a further reason. The sign of the WTA effect on investment is positive. Higher investment costs are a consequence. Further causes via indirect channels might be responsible for lower profits.

The WTA effect on profits may differ between specific types of companies. E. g., in large, export-oriented establishments and in times of low product demand, the WTA influence can deviate from that in other firms. To test this, interaction variables of WTA and firm's characteristics are incorporated in the profit function. The estimates are presented in Table 4. We find that the significantly negative WTA effect on profits is reduced but not completely eliminated compared with other firms or situations if one of the three mentioned characteristics is observed. We should especially emphasize that the hypothesis concerning product demand is confirmed: when product demand is low, profits are positively influenced by WTA. This idea was mentioned in the introduction in the context of two perspectives. However, we cannot be sure that the statistical effects are due to employee behavior on the one hand and employer behavior of the other hand, which is essential for a clear distinction of the two perspectives.

So far, the puzzle of negative WTA effects on profits has not been completely solved. The crude and self-reported measurement of profits may be the first reason. As an alternative, we use the operating surplus (OS = sales-preliminary work-wages). In this case, the sign is positive, but the effect is insignificant-see Table 3, line log(operating

Table 3 Fixed effects instrumental variables estimates for different establishment performance functions with WTA as a regressor

\begin{tabular}{lcr}
\hline & $\beta($ WTA $)$ & std. err. \\
\hline $\log$ (PRODUCTIVITY) & $0.457^{* *}$ & 0.193 \\
$\log ($ WAGES Per EMPLOYEE) & 0.117 & 0.119 \\
$\log ($ INVESTMENTS) & $15.952^{* * *}$ & 2.745 \\
$\log$ (OPERATING SURPLUS) & 0.110 & 0.261 \\
PROFITS & $-3.246^{* * *}$ & 0.960
\end{tabular}

Notes: Control variables are the same as in Table 2 . The WTA variable is instrumented. The identifying variable is prWTA_c, explained in Section 4.1; ${ }^{* *} p<0.05,{ }^{* *} p<0.01$ 
Table 4 Fixed effects instrumental variables estimates with interaction variables - the influence of working time accounts on profits

\begin{tabular}{|c|c|c|c|c|c|c|}
\hline & (1) & & (2) & & (3) & \\
\hline & $\beta$ & std. err & $\beta$ & std. err. & $\bar{\beta}$ & std. err \\
\hline WTA & $-3.358^{* * *}$ & 0.950 & $-3.489^{* * *}$ & 1.019 & $-3.860^{* * *}$ & 1.174 \\
\hline WTA*EXPORT_d & $1.068^{* * *}$ & 0.309 & & & & \\
\hline WTA*FSIZE_I & & & $1.609^{* * *}$ & 0.455 & & \\
\hline WTA*Y2009 & & & & & $1.454^{* * *}$ & 0.417 \\
\hline
\end{tabular}

Notes: The control variables are the same as in Table 3. EXPORT_d (=1 if the firm exports), FSIZE_I (=1 if the firm is large, i.e. 500 or more employees) and Y2009 (=1 if the year is 2009) are dummies; ${ }^{* * *} p<0.01$

surplus). This means OS does not differ statistically between WTA and NON-WTA establishments. Second, costs of WTA installation and operating costs may be responsible for negative effects of WTA on profits. No information exists on this issue. Third, the negotiating power of employees can be another explanation. If qualified workers are especially interested in flexible working time, they have the power to enforce WTA because they can threaten to reduce their working intensity. Establishments accept the introduction of WTA because otherwise, the fall in productivity would be higher than the savings of WTA costs. If the share of graduates and skilled workers is low and if the staff has no threat potential, a company can forego WTA. The descriptive statistics in Table 1 show that the share of graduates and skilled workers is significantly higher in WTA than in other firms. Nevertheless, it cannot be excluded that the employer adopts WTA even though the share of graduates and skilled workers is low. Then, we expect lower profits. This topic is analyzed under 4.3.

\subsection{Results for subgroups - robustness or heterogeneity?}

First, we test whether the results are robust or heterogeneous for specific industries and firms. Second, we analyze whether the influences of WTA on firms' performance indicators vary under WTA contracts with different lengths of compensation periods for time credits. Following section 4.2, the sample in Table 3 is split into firms with higher and lower shares of graduates and skilled workers. No significant loss of profits can be observed under a WTA regime when the share of qualified workers in the establishment is high-see Table 5(1a). This result does not change when operating surplus instead of the categorical profit variable is used-see Table 5(1b). Nevertheless, so far, the sign of all WTA effects on profits is negative. Therefore, we follow another line of argument. Firms introduce WTA to achieve a better adaptation of working hours to fluctuations of demand for goods in order to increase profits. In this case, firms with stronger sales fluctuations are more interested in WTA. We test whether WTA effects on operating surplus are more likely to be positive as sales vary more. First, we ask whether this hypothesis can be confirmed at an industry level. Second, we investigate the firm level. Sales fluctuations are measured by the variation coefficient (v) of $\log (\mathrm{sales})$. In panel (2) of Table 5, industry results are presented. Based on industries with high and low $\mathrm{v}$, we find that in the former WTA induce positive OS effects. In industries with small fluctuations, we observe the opposite result. This outcome is strengthened on the firm level-see panel (3) of Table 5. The 25 percent of firms with the highest variation coefficient (v) of sales have positively significant WTA effects on operating surplus. Other firms do not benefit from working time accounts on average. 
Table 5 Working time accounts (WTA) effects on profits and operating surplus (OS)

B_WTA std.err restriction

(1) Firms with high and low shares of graduates and skilled workers

(a) WTA effect on PROFITS
(i) $\quad-2.292$
3.123
share of graduates $>=0.7$ or share of skilled workers $>=0.7$
(ii) $-2.518^{*}$
1.495
share of graduates $<0.3$ or share of skilled workers $<0.3$

(b) WTA effect on operating surplus (OS)
(i) $\quad-0.337$
0.629
share of graduates $>=0.7$ or share of skilled workers $>=0.7$
(ii) $\quad-0.592^{* * *}$
0.279
share of graduates $<0.3$ or share of skilled workers $<0.3$

(2) Industries with large and small sales fluctuations measured by the variation coefficient (v) - WTA effects on OS
2.530
1.877
INDUSTRY $=$ mining and quarrying $(\mathrm{V}=0.151)$
(ii) $\quad 1.979$
2.945
INDUSTRY = manufacture of motor vehicles $(v=0.188)$
(iii) $\quad 0.350 \quad 0.267$
INDUSTRY $=$ recreational and cultural activities $(\mathrm{V}=0.183)$
(iv) $-1.591^{*} \quad 0.911$
INDUSTRY = agriculture, hunting, forestry, fishing $(v=0.102)$
(v) $\quad-4.970$
3.869
INDUSTRY $=$ architecture, engineering offices $(v=0.108)$
(vi)
$-0.421$
0.449
INDUSTRY $=$ education $(v=0.105)$

(3) Firms with large and small sales fluctuations measured by $\vee$ - WTA effects on OS
(i)
$1.340^{* * *}$
0.503
firms with the $25 \%$ largest sales fluctuations
(ii) $\quad-0.145$
0.161
firms with the $75 \%$ smallest sales fluctuations

Notes: The specifications are the same as in Table $3 ;{ }^{*} p<0.1$ and ${ }^{* *} p<0.01$

In our next step, we investigate whether the WTA effects are robust or heterogeneous under WTA contracts with different lengths of compensation periods for time credits. Information on subgroups of WTA is available only for 2008, 2010 and 2012 waves of the IAB Establishment Panel. In Table 6, the percentage of firms with WTA but differently agreed compensation periods is presented. Three groups are distinguished: less than or equal to 1 year $(\mathrm{CP}<=1 \mathrm{Y})$, more than 1 year $(\mathrm{CP}>1 \mathrm{Y})$ or no fixed compensation period (noFCP). It can be seen that the share of firms with $\mathrm{CP}<=1 \mathrm{Y}$ is the largest one but decreasing in recent years. The opposite tendency is observed for firms with no fixed compensation period, however at a lower level. WTA with a longer compensation period are less widespread, and no clear development is identifiable.

The instrumental variables estimates of Table 3 are extended by an interaction term between WTA and a subgroup indicator, measured by a dummy variable (see Table 6). In Table 7, we present three different random (RE) and fixed effects (FE) estimates, where we restrict our analysis on productivity (PROD) and wages per employee (WpE) effects and where we only show the WTA and the interaction coefficient. The control variables are the same as in Table 3. Based on Hausman tests, the FE estimates should be preferred, although the RE estimates indicate a higher degree of significance. The signs of

Table 6 Descriptive statistics of WTA subgroups, split by years (2008, 2010 and 2012)

\begin{tabular}{|c|c|c|c|c|c|c|}
\hline & \multicolumn{2}{|l|}{2008} & \multicolumn{2}{|l|}{2010} & \multicolumn{2}{|l|}{2012} \\
\hline & mean & sd & mean & sd & mean & sd \\
\hline$C P<=1 Y$ & 0.594 & (0.49) & 0.573 & (0.49) & 0.551 & $(0.50)$ \\
\hline$C P>1 Y$ & 0.130 & $(0.34)$ & 0.142 & (0.35) & 0.134 & (0.34) \\
\hline noFCP & 0.275 & $(0.45)$ & 0.283 & $(0.45)$ & 0.314 & $(0.46)$ \\
\hline
\end{tabular}

Notes: WTA - working time accounts; $s d$ - standard deviation; $C P<=1 \mathrm{Y}(=1$ if compensation period within a year), $C P>1 Y$ $(=1$ if compensation period is more than 1 year), noFCP ( $=1$ if no fixed compensation period is agreed) are dummies 
Table 7 Instrumental variables panel estimates with interaction variables - the influence of specific working time accounts on productivity and wages per employee

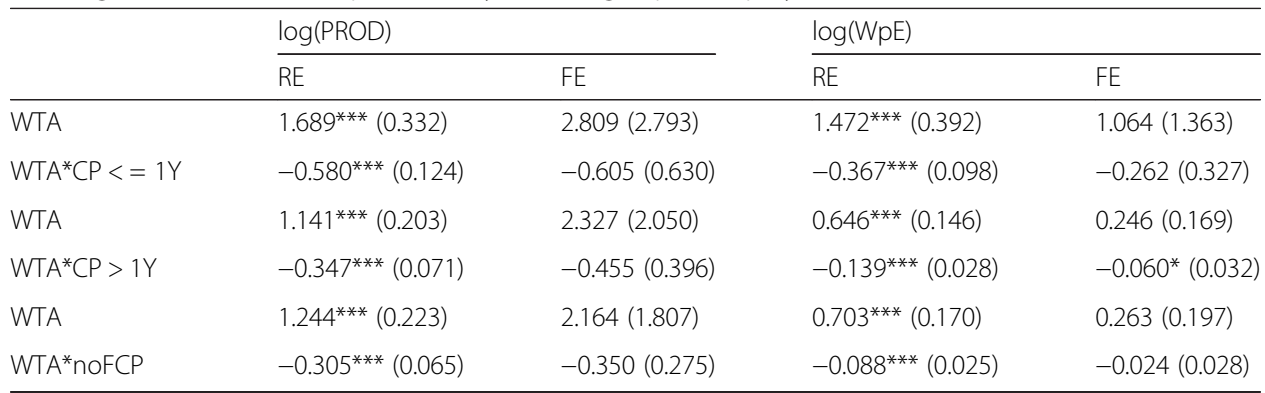

Notes: Basic control variables are the same as those in Tables 2 and 3. Additionally, interaction variables between WTA and the following variables are incorporated: $C P<=1 Y(=1$ if compensation period within a year), $C P>1 Y(=1$ if compensation period is more than 1 year), $\operatorname{noFCP}(=1$ if no fixed compensation period is agreed) are dummies. The WTA variable is instrumented as in Table $3 ;{ }^{*} p<0.1,{ }^{* * *} p<0.01$

the coefficients are the same in RE and FE estimates. It should be noted that in all estimations, the FE coefficients are absolutely larger than the RE coefficients in the productivity function. The opposite is observed in the wage function. All in all, we cannot detect strong influences of the length of the compensation period on the effects of WTA on productivity and wages per employee.

We limit the following interpretation to the FE results. First, only one of the interaction variables is found to have significant effects on the wage per employee. All WTA coefficients stay positive, as in Table 3, lines 1 and 2. The interaction variable reduces the pure WTA influences. In all specifications of the $\log$ (PROD) function the sum of the WTA coefficient and the coefficient of the interaction variable is larger than the WTA coefficient in Table 3. Short compensation periods have stronger effects than longer ones. In other words, the total WTA effects on productivity decrease with the length of compensation periods. From a first view, this does not seem plausible because longer compensation periods mean more flexibility. Then, it is only later necessary to balance positive credits because the compensation period has ended even though employees and the employer may prefer longer working time with the result of higher productivity. However, as the compensation period lengthens, the incentives to work harder decrease. In some sense, the time preference is effective. The earlier longer working hours are compensated by leisure, the more employees try to work well with a high intensity.

One could expect that the total WTA effect is lower if no compensation period is agreed. This is observed in comparison with a one-year compensation period and also but less in comparison with a longer compensation period. Therefore, the coefficient of the interaction WTA*noFCP is surprising. However, no fixed compensation period also includes cases of no restriction. Then, in practice, the horizon can be very long.

\section{Conclusions}

Economists, psychologists and sociologists have investigated the determinants of flexible working time and their effects on both employees and companies. "Working time accounts ... have the potential to further boost flexibility for both employers and employees. However, they are not widely available in all countries ..." (European Foundation for the Improvement of Living and Working Conditions 2012a, p.5). Working time accounts 
(WTA) have become more important in practice in recent years, but they were not the center of empirical investigations. To date, there exist only a few studies on this issue that use individual or firms data for this purpose.

The intention of our paper is to demonstrate that WTA influence the business processes through different channels. To date, this has been an under-researched area. Our empirical investigations show that the major question asks whether firms benefit from WTA and whether WTA help to increase firm performance cannot simply be answered by yes or no. When unobserved firm effects, WTA endogeneity, and firm characteristics are considered, we find that WTA firms have significantly higher productivity and investments than other firms. On average, the wages per employee are the same. The operating surplus does not distinguish between WTA and non-WTA firms, but profits are lower in the former firms.

These results are not valid for all subgroups of firms. Shorter compensation periods for time credits and debits under WTA arrangements should be preferred under the productivity perspective. The seeming contradiction that WTA increase productivity and do not enhance wages per employee but induce lower profits can be resolved. WTA and other costs usually hinder higher profits in the short run, except if sales are highly volatile. In this situation, it is most beneficial for establishments to introduce WTA.

WTA are not a panacea. If the macroeconomic demand for goods is characterized by an economic slump as during the Great Recession in 2009, the balancing force of WTA is not sufficient to hinder layoffs. This is only the case if fluctuations are short and foreseeable. Launov and Wälde (2014) also demonstrated that WTA do not necessarily reduce labor turnover and inhibit rising unemployment during recessions. However, in a situation like the German one during the Great Recession when high-productive firms had surpluses in their WTA in the beginning of the crisis and expected a demand downturn on the product market, they were able to sustain a stronger realized demand downturn than without WTA. For this purpose, economic policy should support the adoption of WTA in the interest of establishments and workers. Adaption costs can be subsidized. Such an instrument is less expensive than short-time work. Hunt (2013, p.94) pointed out that certain regulations are necessary such as ceilings on cumulated overtime hours to be compensated with time off and a time window for such compensations. Heigh ceilings and long windows may cause problems in the case of "accidents" such as firm insolvencies and mass layoffs. A further advantage of WTA is that employees prefer WTA more than company-level pacts because the latter are associated with certain problems. Employers' pledges are not always fulfilled (Hübler 2005, Bellmann 2014). Investments are a by-product of WTA and are not necessarily associated with specific concessions of employees within company-level pacts.

Future research might usefully be threefold. First, the analysis needs to be supplemented by comparable studies with individual data. Then, we can better evaluate the extent to which establishment results are driven by individual preferences for WTA. Second, it would be instructive to carry out analogous empirical investigations in other countries. Then, we can see whether the practice in some countries can be a role model for others. Third, we need more long-run investigations. Then, we can assess whether not only sales-varying firms but also other firms benefit from WTA in the long run under a profit perspective. 


\section{Appendix}

Table 8 Specification tests for different establishment performance indicator functions with WTA as a regressor

\begin{tabular}{lllccc}
\hline & BP & HAUS & EXO & OIR & WI \\
\hline $\log ($ PRODUCTIVITY) & $6691^{* * *}$ & $1068^{* * *}$ & $71.47^{* * *}$ & 0.04 & 171.34 \\
$\log ($ WAGES per EMPLOYEE) & $6481^{* * *}$ & $697^{* * *}$ & $372.84^{* * *}$ & 0.29 & 248.12 \\
$\log ($ INVESTMENTS) & $5397^{* * *}$ & $280^{* * *}$ & $423.09^{* * *}$ & 0.10 & 294.00 \\
$\log ($ OPERATING SURPLUS) & $15,83^{* * *}$ & $2008^{* * *}$ & $247.48^{* * *}$ & $33.80^{* * *}$ & 923.37 \\
PROFITS & $1775^{* * *}$ & $148^{* * *}$ & $13.89^{* * *}$ & 0.68 & 180.72 \\
\hline
\end{tabular}

Notes: We test $\mathrm{H} \_0$ for no time-invariant firm effects (Breusch-Pagan test - BP), no correlation between firm effects and regressors (random vs. fixed (Hausman test - HAUS)), exogeneity (Durbin-Wu-Hausman test - EXO), no overidentifying restrictions (OIR) und weak instruments (Stock-Yogo test - WI). Test statistics are presented in the table, where BP, HAUS, EXO and OIR are $\chi^{2}$ distributed. WI displays minimum eigenvalue statistics. All test statistics in column WI indicate that the eigenvalue is larger than the critical value at $p<0.05$, that $\mathrm{H}_{-} 0$ (weak instruments) has to be rejected; ${ }^{* * *} p<0.01$ 
Table 9 Log productivity - $\log (P R O D)$ - fixed effects instrumental variables estimates

\begin{tabular}{|c|c|c|}
\hline Regressors & $\beta$ & \\
\hline WORKING TIME ACCOUNTS & $0.4572^{* *}$ & $0.4568^{* *}$ \\
\hline $\log (G R A D U A T E S)$ & 0.0036 & 0.0020 \\
\hline log(SKILLED WORKERS) & $0.0445^{* * *}$ & $0.0443^{* * *}$ \\
\hline log(FIRM SIZE) & $-0.0793^{* * *}$ & $-0.0784^{* * *}$ \\
\hline log(INVESTMENTS) & $0.0148^{* * *}$ & $0.0143^{* * *}$ \\
\hline LABOR HORDING & $-0.0770^{* * *}$ & $-0.0753^{* * *}$ \\
\hline FIXED-TERM EMPLOYMENT & 0.0058 & 0.0048 \\
\hline PART-TIME WORK & 0.0081 & 0.0111 \\
\hline TEMPORARY WORK & -0.0017 & -0.0026 \\
\hline OVERTIME WORK & -0.0113 & -0.0117 \\
\hline EXTRA PAYMENT & -0.0005 & 0.0007 \\
\hline DEPARTED EMPLOYEES & $-0.0012^{* * *}$ & $-0.0012^{* * *}$ \\
\hline LAY-OFFS & 0.0003 & $0.0004^{* *}$ \\
\hline QUITS & $0.0016^{* * *}$ & $0.0015^{* * *}$ \\
\hline MUTUAL DISMISSALS & $-0.0006^{* *}$ & $-0.0005^{* *}$ \\
\hline RELOCATIONS & $0.0011^{* * *}$ & $0.0011^{* * *}$ \\
\hline RETIREMENTS & 0.0003 & 0.0003 \\
\hline EARLY RETIREMENTS & $0.0013^{* * *}$ & $0.0013^{* * *}$ \\
\hline PLANT CLOSURE & $-0.0764^{* * *}$ & $-0.0758^{* * *}$ \\
\hline OUTSOURCING & $-0.0469^{* *}$ & $-0.0483^{* *}$ \\
\hline STARBUST & $-0.1770^{* * *}$ & $-0.1833^{* * *}$ \\
\hline REORGANIZATION & $0.0774^{* * *}$ & $0.0719^{* * *}$ \\
\hline COMPETITIVE PRESSURE & -0.0015 & -0.0014 \\
\hline NEW PRODUCTS & 0.0044 & 0.0028 \\
\hline NEW PROCEDURE & $-0.0188^{* * *}$ & $-0.0176^{* * *}$ \\
\hline TECHNICAL STATUS & $-0.0246^{* * *}$ & $-0.0246^{* * *}$ \\
\hline Y2008 & $0.0346^{* * *}$ & $0.0585^{* * *}$ \\
\hline Y2009 & $0.0250^{* * *}$ & $0.0247^{* * *}$ \\
\hline Y2010 & $-0.0489^{* * *}$ & $-0.0490^{* * *}$ \\
\hline Y2011 & -0.0053 & -0.0049 \\
\hline Y2012 & $0.0137^{* *}$ & $0.0141^{* *}$ \\
\hline INDUSTRIES & no & yes \\
\hline REGIONS & no & yes \\
\hline N & 47824 & 47824 \\
\hline Number of groups & 2787 & 2787 \\
\hline
\end{tabular}

Notes: WTA is instrumented by prWTA_c. On the right-hand side, in addition to 5 year dummies, 14 industry dummies and 16 regional dummies (Bundesländer) are incorporated; ${ }^{* *} p<0.05 ;{ }^{* * *} p<0.01$ 


\section{Competing interests}

The IZA Journal of European Labor Studies is committed to the IZA Guiding Principles of Research Integrity. The authors declare that they have observed these principles.

\section{Acknowledgements}

We are grateful to a referee for valuable suggestions and remarks which improved the paper substantially. Furthermore, we would like to thank Michael Beckmann, Thomas Cornelissen, Knut Gerlach, Hans-Dieter Gerner, Robert A. Hart and Wolfgang Meyer for their helpful comments.

Responsible editor: Alan Barrett.

\section{Author details}

${ }^{1}$ Institute for Employment Research, Regensburger Straße 104, D-90478 Nürnberg, Germany. ${ }^{2}$ Institut für Empirische Wirtschaftsforschung, Leibniz Universität Hannover, Königsworther Platz 1, D-30167 Hannover, Germany.

Received: 6 August 2015 Accepted: 2 November 2015

Published online: 10 December 2015

\section{References}

Addison JT, Schnabel C, Wagner J (2001) Works councils in Germany: their effects on establishment performance. Oxf Econ Pap 53:659-694

Balleer A, Gehrke B, Merkl C (2014) Some surprising facts about working time accounts and the business cycle. Kiel Working Paper No. 1955

Baltagi BH (2005) Econometric analysis of panel data, 3rd ed., John Wiley \& Sons, Chichester.

Beckmann M, Cornelissen T, Kräkel M (2015) Self-managed working time and employee effort: theory and evidence. SOEPpapers No. 768

Bellmann L (2014) Do in-plant alliances foster employment? IZA World of Labor

Bellmann L, Gerner HD (2011) Reversed roles? Wage and employment effects of the current crisis. In: Immervoll H, Peichl A, Tatsiramos K (eds) Who loses in the downturn? Economic crisis, employment and income distribution. Bingley, Emerald, pp 181-206

Bellmann L, Gewiese T (2004) Die Dynamik der Nutzung von Arbeitszeitkonten - theoretische Ansätze und Längsschnittanalysen mit dem IAB-Betriebspanel. In: L. Bellmann und C. Schnabel (Hrsg.), Betriebliche Arbeitszeitpolitik im Wandel, BeitrAB 288, Nürnberg, 139-184

Bellmann L, Hübler O (2015) Are working time accounts beneficial for German establishments? Working Paper

Bellmann L, Ellguth P, Gerner HD (2012) Betriebliche Arbeitszeiten - Auswertungen des IAB-Betriebspanels. In: BeckerStoll, F., Klös, H.-P., Rainer, H., G. Thüsing (Hrsg.), Expertisen zum Achten Familienbericht „Zeit für Familie". München, 397-418

Berg P, Appelbaum E, Bailey T, Kalleberg AL (2004) Contesting time: International comparisons of employee control of working time. Ind Labor Relat Rev 57:331-349

Chung H, Tijdens K (2009) Working time flexibility components of companies in Europe, University of Amsterdam, Working Paper 09-84

Crompton R (2002) Employment, flexible working and the family. Br J Sociol 53:537-558

Dex S, Scheibl F (2001) Flexible and family-friendly working arrangements in UK - Based SMEs: business cases. Br J Ind Relat 39:411-431

Efron B, Hastie T, Johnstone I, Tibshirani R (2004) Least angle regression. Ann Stat 32:407-451

European Foundation for the Improvement of Living and Working Conditions (2012a) Working time in the EU, Dublin

European Foundation for the Improvement of Living and Working Conditions (2012b) Organisation of working time: implications for productivity and working conditions - overview report, Dublin

Fischer G, Janik F, Müller D, Schmucker A (2009) The IAB establishment panel - things users should know. J Appl Soc Sci Stud 129:133-148

Gerner HD (2012) Die Produktivitätsentwicklung und die Rolle von Arbeitszeitkonten während der Großen Rezession 2008/2009: Ergebnisse auf der Grundlage des IAB Betriebspanels. Zeitschrift für Personalforschung 26:30-47

Groß H, Munz E, Seifert H (2000) Verbreitung und Struktur von Arbeitszeitkonten. Arbeit 9:217-229

Herzog-Stein A, Zapf I (2014) Navigating the great recession: the impact of working-time accounts in Germany. Ind Labor Relat Rev 67:891-925

Houseman SN (2001) Why employers use flexible staffing arrangements: evidence from an establishment survey. Ind Labor Relat Rev 55:149-170

Hübler O (2005) Sind betriebliche Bündnisse für Arbeit erfolgreich? Jahrbücher für Nationalökonomie und Statistik 225:630-652

Hunt J (2013) Flexible work time in Germany: do workers like it and how have employers exploited it over the cycle? Perspektiven der Wirtschaftspolitik 14:67-98

Kelliher C, Anderson D (2010) Doing more with less? Flexible working practices and the intensification of work. Hum Relat 63:83-106

Launov A, Wälde K (2014) Working time accounts and unemployment, Working Paper

Lindecke C (2008) Flexible Arbeitszeiten im Betrieb - Betriebs- und Dienstvereinbarungen. Fallstudien, Bund-Verlag, Frankfurt a.M

Lott M (2013) Arbeitszeitverkürzung für Weiterbildung im Spiegel betrieblicher Einschätzung. WSI Mitteilungen $66: 255-263$

Ludewig O (2001) Betriebliche Bestimmungsgründe von Arbeitszeitkonten. Mitteilungen aus der Arbeitsmarkt- und Berufsforschung 34:302-313

Orpen C (1981) Effect of flexible working hours on employee satisfaction and performance: a field experiment. J App Psychol 66:113-115 
Platenga J, Remery C (2010) Flexible working time arrangements and gender equality. A comparative review in 30 European countries, Rome

Possenriede D (2014) The economics of temporal and locational flexibility of work, Dissertation, University of Utrecht Schein VE, Maurer EH, Novak JF (1977) Impact of flexible working hours on productivity. J Appl Psychol 62:463-465

Seifert H (2004) Flexibility through working-time accounts: reconciling economic efficiency and individual time requirements, WSI Discussion Paper No. 130

Wotschack P, Hildebrandt E (2007) Long-term working-time accounts and life-course policies. Preliminary results of a representative company survey, WZB discussion paper no. SP I 2007-109

Zapf I (2012) Flexibilität am Arbeitsmarkt durch Überstunden und Arbeitszeitkonten. Messkonzepte, Datenquellen und Ergebnisse im Kontext der IAB-Arbeitszeitrechnung, IAB-Forschungsbericht 3/2012, Nürnberg

Zapf I, Brehmer W (2010) Arbeitszeitkonten haben sich bewährt, IAB-Kurzbericht 22/2010

Zickert K (2007) Förderung der beruflichen Qualifizierung durch Weiterbildungs- und Arbeitszeitmanagement. Ergebnisse einer Betriebsbefragung. IAB-Forschungsbericht, Nr. 11/2007

\section{Submit your manuscript to a SpringerOpen ${ }^{\circ}$ journal and benefit from:}

- Convenient online submission

- Rigorous peer review

- Immediate publication on acceptance

- Open access: articles freely available online

- High visibility within the field

Retaining the copyright to your article

Submit your next manuscript at $>$ springeropen.com 